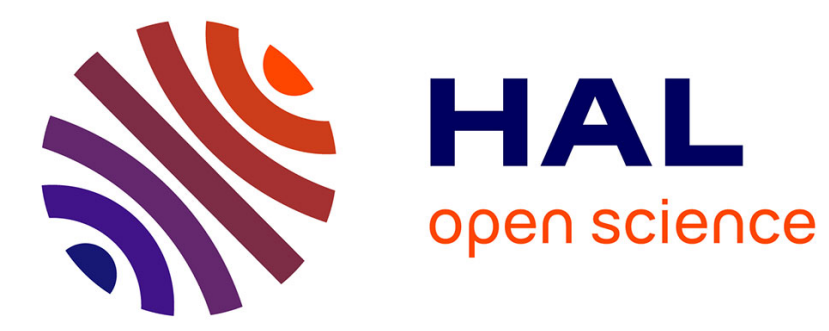

\title{
Safety assessment of dairy microorganisms: The Lactococcus genus
}

Erick Casalta, Marie-Christine M.-C. Montel

\section{To cite this version:}

Erick Casalta, Marie-Christine M.-C. Montel. Safety assessment of dairy microorganisms: The Lactococcus genus. International Journal of Food Microbiology, 2008, 126 (3), pp.271-273. 10.1016/j.ijfoodmicro.2007.08.013 . hal-02667687

\section{HAL Id: hal-02667687 https://hal.inrae.fr/hal-02667687}

Submitted on 31 May 2020

HAL is a multi-disciplinary open access archive for the deposit and dissemination of scientific research documents, whether they are published or not. The documents may come from teaching and research institutions in France or abroad, or from public or private research centers.
L'archive ouverte pluridisciplinaire HAL, est destinée au dépôt et à la diffusion de documents scientifiques de niveau recherche, publiés ou non, émanant des établissements d'enseignement et de recherche français ou étrangers, des laboratoires publics ou privés. 


\title{
Safety assessment of dairy microorganisms: The Lactococcus genus is $^{2}$
}

\author{
Erick Casalta $^{\mathrm{a}, *}$, Marie-Christine Montel $^{\mathrm{b}}$ \\ a INRA, UR45 Recherches sur le Développement de l'Elevage, Campus Grossetti, F-20250 Corté, France \\ b INRA, UMT545 Recherches Fromagères, 36, rue de Salers, F-15000 Aurillac, France
}

\begin{abstract}
The Lactococcus genus includes 5 species. Lactococcus lactis subsp. lactis is the most common in dairy product but L. garviae has been also isolated. Their biotope is animal skin and plants. Owing to its biochemical characteristics, strains of L. lactis are widely used in dairy fermented products processing. Cases of human infections due to lactococci are very seldom reported even if Lactococcus garviae can be involved in fish diseases. Then L. lactis can be considered as safe and it is most commonly considered as Generally Recognized as Safe.
\end{abstract}

(C) 2008 Published by Elsevier B.V.

Keywords: Lactococcus; Taxonomy; Dairy use; Human safety

\section{Introduction}

The genus Lactococcus was proposed by Schleifer and colleagues in 1985 to reclassify some species of the genera Streptococcus (Lancefield group N lactic streptococci) and Lactobacillus. It has been defined on the basis of chemotaxonomic studies confirmed by 16s rRNA sequencing (Schleifer et al., 1985; Schleifer and Killper-Bälz, 1987; Collins et al., 1989). The Lactococcus genus includes five species, $L$. garvieae (formerly E. serolicida), L. piscium, L. plantarum, L. raffinolactis (formerly S. raffinolactis) and L. Lactis, which is differentiated into subspecies L. lactis subsp. cremoris, L. lactis subsp. hordniae (formerly Lactobacillus hordniae) and L. lactis subsp. lactis (formerly Lactobacillus xylosus, Streptococcus lactis) (www.bacterio.cict.fr).

Lactococci are Gram positive cocci and belong to the group of Lactic Acid Bacteria. They are homofermentative and exclusively produce $\mathrm{L}(+)$ lactic acid. They are not $\beta$ hemolytic and they are poorly $\alpha$ hemolytic.

\footnotetext{
Contribution to the safety assessment of technological microflora found in fermented dairy products, PART II.

* Corresponding author.

E-mail address: eca@corte.inra.fr (E. Casalta).
}

\section{Biotope and concerned food}

Lactococci are generally found on plants and the skins of animals. L. plantarum is mainly isolated from plants, $L$. garvieae from fish, animals and milk, and L. piscium from salmon (Williams et al., 1990). The presence of lactococci in raw milk is due to contamination from forage during milking. The two lactococci most commonly found in raw milk, cheese and other dairy products are L. lactis subsp. lactis and L. lactis subsp. cremoris. These two subspecies generally reach a high level $\left(>10^{8} \mathrm{CFU} \mathrm{g}^{-1}\right)$ as early as the first day of manufacturing and maintain it throughout the ripening period of many raw milk cheeses such as Camembert (Corroler et al., 1999), Serra (Macedo et al., 1996), Venaco (Casalta, 2003) and Pecorino Sardo (Ledda et al., 1996). L. raffinolactis has occasionally been found in raw milk and cheeses (Perez Elortondo et al., 1999; Lopez-Diaz et al., 2002). L. garvieae may also be isolated from raw milk (Villani et al., 2001) and raw milk cheeses: PDO Salers (Callon et al., 2004), Egyptian cheeses (El-Baradei et al., 2005), Jben cheese (Ouadghiri et al., 2005), Italian Piedmontese PDO Toma cheeses (Fortina et al., 2003). A study of 35 European artisanal dairy products indicated lactococci as the most commonly found LAB genus, accounting for $38 \%$ of the bacterial isolates identified (Cogan et al., 1997).

L. lactis subsp. lactis and to a lesser extent L. lactis subsp. cremoris have long been extensively used in starter cultures 
for dairy fermentation (i.e. in cheeses, sour cream and butter), composed of single or multiple strains with or without other lactic acid bacteria (Beresford et al., 2001). Their main role in dairy fermentation is acidification, mainly by producing L-lactic acid. They contribute to the development of texture by producing exopolysaccharides, or to flavor by producing aromatic compounds (alcohols, ketones, aldehydes) or by citrate, amino acid or fat metabolism (Smit et al., 2005). They can also be used for food preservation due to their ability to produce organic acids and bacteriocins, nisin being the best characterized and recognized (Delves-Broughton et al., 1996). Their use as probiotics has been also considered (Ouwehand et al., 1999). The annotation of the genomes of different subspecies will undoubtedly open up new prospects for identifying new useful functions in the species (Kok et al., 2005). It will also be a great help in assessing the safety of lactococci (Kok et al., 2005).

\section{Taxonomy}

The identification of the most common Lactococcus species found in dairy products can be successfully performed by rapid and accurate molecular techniques.

PCR-DGGE (denaturating gradient gel electrophoresis) analyses can be used for differentiating Lactococcus lactis from other lactic acid bacteria (Coppola et al., 2001). rRNA oligonucleotide probes have been designed for identifying $L$. lactis subsp. cremoris (Salama et al., 1991). Several PCR or multiplex PCR reactions are now available, exploiting the diversity of sequences of 16 SrRNA genes in L. lactis (Pu et al., 2002) and L. garvieae (Zlotkin et al., 1998) and the polymorphism of the $16 \mathrm{~S}-23 \mathrm{~S}$ rDNA spacer region (Blaiotta et al., 2002) or other functional genes, histidine biosynthesis operon (Corroler et al., 1999), acmA gene (Garde et al., 1999), sodA gene (Fihman et al., 2006). The genetic diversity of Lactococcus can be analyzed by random polymorphism DNA (RAPD) (Tailliez et al., 1998) or multiple locus microsatellite analysis (Quénée et al., 2005) for L. lactis or by pulsed-field gel electrophoresis (PFGE) for L. garvieae (Vela et al., 2000).

Knowledge of the L. lactis genome will make it easy, in the future, to develop new genomic tools for increasingly reliable identification (Kok et al., 2005).

\section{Safety assessment}

Members of Lactococcus genus are most commonly classed as Generally Recognized as Safe (GRAS) (Salminen et al., 1998). L. lactis cannot be considered as an opportunist pathogen, as only two cases of endocarditis have been reported in the medical literature over a period of fifty years (Wood et al., 1955; Mannion and Rothburn, 1990).

Lactococcus garvieae has been associated with septicemic infections of fish, mainly in intensive modern aquaculture; it is the main risk factor for the Mediterranean European trout industry (Schmidtke and Carson, 2003; Vela et al., 2000; Eyngor et al., 2004). It has been also isolated from bovine mastitis (Teixeira et al., 1996). Human infections due to $L$. garviae are scarce, since only six cases has been described, all of which concerned elderly or immunosuppressed patients. $L$. garvieae has been incriminated in three cases of infection of prosthetic valves (Fihman et al., 2006), one case of native valve infection (Fefer et al., 1998), one case of osteomyelitis (James et al., 2000) and one case of bacteremia with a liver abscess (Mofredj et al., 2000). The number of cases may be underestimated as the bacterial agent responsible for endocarditis cases has not always been identified with certainty.

\section{Conclusion}

Lactococci are ubiquitous in the environment and in food. They are widely used as starters, with a long history of use for the sake of their technological properties, especially in dairy products, from small-scale manufacture to industrial-scale processes. Their identification no longer poses problems.

Lactococci from dairy products can be generally considered safe, in view of their extensive, daily consumption by humans and their low incidence in human infections.

\section{References}

Beresford, T.P., Fitzsimons, N.A., Brennan, N.L., Cogan, T.M., 2001. Recent advances in cheese microbiology. International Dairy Journal 11, 259-274.

Blaiotta, G., Pepe, O., Mauriello, G., Villani, F., Andolfi, R., Moschett, G., 2002. 16 S-23 S rDNA intergenic spacer region polymorphism of Lactococcus garvieae, Lactococcus raffinolactis and Lactococcus lactis as revealed by PCR and nucleotide sequence analysis. Systematic and Applied Microbiology 25, 520-527.

Callon, C., Millet, L., Montel, M.C., 2004. Diversity of lactic acid bacteria isolated from AOC Salers cheese. Journal of Dairy Research 71, 231-244.

Casalta, E., 2003. Bases scientifiques de la qualité du Venaco, fromage traditionnel au lait cru. Mise au point de ferments sélectionnés spécifiques. Thèse de microbiologie, Université de Bourgogne. ENSBANA, Dijon (136 p.).

Collins, M.D., Ash, C., Farrow, J.A.E., Wallbanks, S., Williams, A.M., 1989. $16 \mathrm{~s}$ ribosomal ribonucleic acid sequence analyses of lactococci and related taxa. Description of Vagococcus fluvialis gen. nov., sp.nov. Journal of Applied Microbiology 67, 453-467.

Cogan, T.M., Barbosa, M., Beuvier, E., Bianchi-Salvadori, B., Cocconcelli, P.S., Fernandes, I., Gomez, J., Gomes, R., Kalantzopoulos, G., Ledda, A., Medina, M., Rea, M.C., Rodriguez, E., 1997. Characterisation of the lactic acid bacteria in artisanal dairy products. Journal of Dairy Research 64, 409-421.

Coppola, S., Blaiotta, G., Ercolini, D., Moschetti, G., 2001. Molecular evaluation of microbial diversity occurring in different types of Mozzarella cheese. Journal of Applied Microbiology 90, 414-420.

Corroler, D., Desmasures, N., Gueguen, M., 1999. Correlation between polymerase chain reaction analysis of the histidine biosynthesis operon, randomly amplified polymorphic DNA analysis and phenotypic characterization of dairy Lactococcus isolates. Applied Microbiology and Biotechnology 51, 91-99

Delves-Broughton, J., Blackburn, P., Evans, R.J., Hugenholtz, J., 1996. Applications of the bacteriocin nisin. Antonie van Leeuwenhoek 69, 193-202.

El-Baradei, G., Delacroix-Buchet, A., Pery, P., Ogier, J.C., 2005. Occurrence of Lactococcus garvieae in four types of Egyptian cheeses by specific polymerase chain reaction assay. Egyptian Journal of Dairy Science 33, 35-41.

Eyngor, M., Zlotkin, A., Ghittino, C., 2004. Clonality and diversity of the fish pathogen Lactococcus garvieae in Mediterranean countries. Applied and Environmental Microbiology 70, 5132-5137.

Fefer, J.J., Ratzan, K.R., Sharp, S.E., Saiz, E., 1998. Lactococcus garvieae endocarditis: report of case and review of the literature. Diagnostic Microbiology and Infectious Disease 32, 127-130. 
Fihman, V., Raskine, L., Barrou, Z., Kiffe, C., Riahi, J., Berçot, B., Sanson-Le Pors, M.J., 2006. Lactococus garvieae endocarditis: identification by $16 \mathrm{~S}$ rRNA and sodA sequence analysis. Journal of Infection 52, e3-e6.

Fortina, M.G., Ricci, G., Acquati, A., Zeppa, G., Gandini, A., Manachini, P.L., 2003. Genetic characterization of some lactic acid bacteria occurring in an artisanal protected denomination origin (PDO) Italian cheese, the Toma piemontese. Food Microbiology 20, 397-404.

Garde, S., Babin, M., Gaya, P., Nuñez, M., Medina, M., 1999. PCR amplification of the gene acm A differentiates Lactococcus lactis subsp. lactis and L. lactis subsp. cremoris. Applied and Environmental Microbiology 65, 5151-5153.

http://www.bacterio.cict.fr.

James, P.R, Hardman, S.M., Patterson, D.L., 2000. Osteomyelitis and possible endocarditis secondary to Lactococcus garvieae: a first case report. Postgraduate Medical Journal 76, 301-303.

Kok, J., Buist, G., Zomer, A.L., van Hijum, S.A.F.T., Kuipers, O.P., 2005. Comparative and functional genomics of lactococci. FEMS Microbiology Reviews 29, 411-433.

Ledda, A., Floris, R., Mannu, L., Scintu, M.F., 1996. Studies on the microbial population and ecosystem of Pecorino Sardo cheese made from raw ewe's milk. Flora 3rd plenary meeting, Thessaloniki, pp. 89-95. 10-12 october.

Lopez-Diaz, T.M., Alonso, C., Roman, C., Garcia-Lopez, M.L., Moreno, B., 2002. Lactic acid bacteria isolated from a hand made blue cheese. Food Microbiology 17, 23-32.

Macedo, A.C., Costa, M.L., Malcata, F.X., 1996. Changes in the microflora of Serra cheese: evolution throughout ripening time, lactation period and axial location. International Dairy Journal 6, 79-94.

Mannion, P.T., Rothburn, M.M., 1990. Diagnosis of bacterial endocarditis by Streptococcus lactis and assisted by immunoblotting of serum antibodies. Journal of Infection 21, 317-326.

Mofredj, A., Baraka, D., Cadrane, J.F., Le Maitre, P., Kloeti, G., Dumont, J.L., 2000. Lactococcus garvieae septicemia with liver abscess in an immunosuppressed patient. American Journal of Medicine 109, 513-514.

Ouadghiri, M., Amar, M., Vancanneyt, M., 2005. Biodiversity of lactic acid bacteria in Moroccan soft white cheese (Jben). FEMS Microbiology Letters 251, 267-271.

Ouwehand, A.C., Kirjavainen, P.V., Grönlund, M., Isolauri, M., Salminen, S.J., 1999. Adhesion of probiotic micro-organisms to intestinal mucus. International Dairy Journal 9, 623-630.

Perez Elortondo, F.J., Aldamiz Echobarria, P., Albisu, M., Barcina, Y., 1999. Indigenous lactic acid bacteria in Idiazabal ewes' milk cheese. International Dairy Journal 8, 725-732.

Pu, Z.Y., Dobos, M., Limsowtin, G.K.Y., Powell, I.B., 2002. Integrated polymerase chain reaction-based procedures for the detection and identification of species and subspecies of the Gram-positive bacterial genus Lactococcus. Journal of Applied Microbiology 93, 353-361.

Quénée, P., Lepage, E., Kim, W.S., Vergnaud, G., Gruss, A., 2005. Minisatellite polymorphism as a tool to distinguish closely related Lactococcus lactis strains. FEMS Microbiology Letters 248, 101-109.
Salama, M., Sandine, W., Giovannoni, S., 1991. Development and application of oligonucleotide probes for identification of Lactococcus lactis subsp. cremoris. Applied and Environmental Microbiology 57, 1313-1318.

Salminen, S., von Wright, A., Morelli, L., Marteau, P., Brassart, D., de Vos, W.M., Fondén, R., Saxelin, M., Collins, K., Mogensen, G., Birkeland, S.E., MattilaSandholm, T., 1998. Demonstration of safety of probiotics - a review. International Journal of Food Microbiology 44, 93-106.

Schleifer, K.H., Kraus, J., Dvorak, C., Kilpper-Bälz, R., Collins, M.D., Fischer, W., 1985. Transfer of Streptococcus lactis and related streptococci to the genus Lactococcus gen. nov. Systematic and Applied Microbiology 6, 183-195.

Schleifer, K.H., Killper-Bälz, R., 1987. Molecular and chemotaxonomic approaches to the classification of streptococci, enterococci and lactococci: a review. Systematic and Applied Microbiology 10, 1-19.

Schmidtke, L.M., Carson, J., 2003. Antigen recognition by rainbow trout (Oncorhyncus mykiss) of whole cell proteins expressed by Lactococcus garvieae when obtained directly from fish and under iron limited culture conditions. Veterinary Research 93, 63-71.

Smit, G., Smit, B.A., Engels, W.J.M., 2005. Flavour formation by lactic acid bacteria and biochemical flavour profiling of cheese products. FEMS Microbiology Reviews 29, 591-610.

Tailliez, P., Tremblay, J., Ehrlich, S.D., Chopin, A., 1998. Molecular diversity and relationship within Lactococcus lactis, as revealed by randomly amplified polymorphic DNA (Rapd). Systematic and Applied Microbiology $21,530-538$.

Teixeira, L.M., Merquior, V.L., Vianni, M.C.E., Carvalho, M.G.S., Fracalanzza, S.E.L., Steigerwalt, A.G., Brenner, D.J., Facklam, R.R., 1996. Phenotypic and genotypic characterization of atypical Lactococcus garvieae strains isolated from water buffalos with subclinical mastitis and confirmation of $L$. garvieae as a senior subjective synonym of Enterococcus seriolicida. International Journal of Systematic Bacteriology 46, 664-668.

Vela, A.I., Vasquez, J., Gibello, A., Blanco, M.M., Moreno, M.A., Liebana, P., Albendea, C., Alcala, B., Mendez, A., Dominguez, L., FernandezGarayzabal, J.F., 2000. Phenotypic and genetic characterization of Lactococcus garvieae isolated in Spain from lactococcosis outbreaks and comparison with isolates of other countries and sources. Journal of Clinical Microbiology 38, 3791-3795.

Villani, F., Aponte, M., Blaiotta, G., Mauriello, G., Pepe, O., Moschetti, G., 2001. Detection and characterization of a bacteriocin, garviecin L1-5, produced by Lactococcus garvieae isolated from raw cow's milk. Journal of Applied Microbiology 90, 430-439.

Williams, A.M., Fryer, J.L., Collins, M.D., 1990. Lactococcus piscium sp. nov. a new Lactococcus species from salmonid fish. FEMS Microbiology Letters $68,109-114$.

Wood, H.F., Jacobs, K., McCarty, M., 1955. Streptococcus lactis isolated from a patient with subacute bacterial endocarditis. American Journal of Medicine $18,345-347$

Zlotkin, A., Eldar, A., Ghittino, C., Bercovier, H., 1998. Identification of Lactococcus garvieae by PCR. Journal of Clinical Microbiology 36, 983-985. 